\title{
Public Aquariums in Turkey
}

\author{
Pınar Çelik ${ }^{1^{*}}$ (D) Ebru Yalçın Ülger ${ }^{2}$ (iD \\ ${ }^{1}$ Çanakkale Onsekiz Mart University, Faculty of Marine Sciences and Technology, Department of Aquaculture, Çanakkale, Turkey \\ ${ }^{2}$ Bursa Uludağ University, Faculty of Veterinary Medicine, Department of Physiology, Bursa, Turkey
}

\section{ARTICLE INFO}

Article History:

Received: 04.11.2019

Received in revised form: 30.12.2019

Accepted: 03.01.2020

Available online: 10.01.2020

Keywords:
Public aquarium
Ornamental fish trade
Aquarium
Aquarium fish
Turkey

\begin{abstract}
A B S T R A C T
This study has presented information in order to reveal the general condition of the activities of public aquariums in Turkey. Firstly, the location and number of public aquariums in Turkey are determined. Afterward, survey questions were prepared, which could show these business profiles. After the surveys have been prepared, some businesses were visited and the authorities were talked face to face. The business officials whom we could not visit were contacted by telephone and e-mail. In the survey, care has been taken not to ask for information that may transgress the public disclosure policy. The right to answer every question is left to the authorities' preference. For these reasons, the information provided about the enterprises can only be sufficient to reveal the general profile of the enterprises. According to this survey, a total of 13 large public aquariums in Turkey have been identified in 2019 and there is a large tunnel aquarium under construction. While 5 of the public aquariums of Turkey are in İstanbul, and 3 of them are located in Ankara, there is one public aquarium in Antalya, Bursa, Diyarbakır, Eskişehir and İzmir provinces. The majority of these aquariums (8) are located in or near shopping centers, the others (5) were located in the parking areas. In aquariums, whereas sea creatures are allocated more space, the areas reserved for freshwater creatures are less. Most of the aquariums have educational activities as well as entertaining activities. Aquaculture engineers, aquaculture technicians, aquanauts, veterinarians, biologists, graduates of fisheries technology and underwater technologies are the occupational groups that are employed in public aquariums.
\end{abstract}

Please cite this paper as follows:

Çelik, P., Yalçın Ülger, E. (2020). Public Aquariums in Turkey. Marine Science and Technology Bulletin, 9(1): 1-6.

\section{Introduction}

The history of public aquariums dates back to the 19th century (Karydis, 2011). These aquariums, which consist of large volume or a large number of small volume aquariums made of various materials, are called Public Aquarium or City Aquarium. The first large public aquarium in the world, known as the Fish House, was built in 1853 at the London Zoo with the name The London Zoo (Brunner, 2003). The second-largest aquarium was opened in Europe, Berlin (Karydis, 2011). Following the aquarium in Berlin, a large public aquarium was opened in Paris. Since the second half of the 1800s, people's interest in aquariums has gradually increased. Aquarium magazines began to be published since 1876 as The New York Aquarium Journal. In 1893, the first aquarist community was established in New York, The United

\footnotetext{
* Corresponding author

E-mail address: pinarakaslan@yahoo.com (P. Çelik)
} 
States of America (Karydis, 2011). Today, large public aquariums continue to operate in many countries, notably Europe, the United States, Canada, and the Far East. In the last 30 years, technological developments in fish farming have contributed to the development of technical equipment used in aquariums (Barnabe, 1989; Huguenin and Colt, 1992). The fact that the transfer of living beings between countries has become easier and has accelerated the development of aquariums all over the world. Nowadays, most of the large public aquariums operating around the world have been built in the last 30 years (Karydis, 2011). In Turkey, the first large public aquarium began to operate in İstanbul in 2009. The number of public aquariums increased one by one in the following years reached to 13 in 2019. In this study, detailed information about the large public aquariums operating in Turkey is presented. Identification of the current status of such public aquarium establishments and publications of the data obtained are important to be the source of new studies in this field.

\section{Material and Methods}

In the study, 13 public aquariums operating in Turkey were examined. The data presented in the study were collected in 2018. Firstly, current enterprises have been identified. Then, information was obtained from the enterprises with the questionnaires prepared in advance. The questionnaires were prepared in order to reveal the general description of the companies. For this purpose, questions were asked to describe the general status of the enterprise such as total area occupied, total aquarium volumes, aquarium sizes/numbers, the species they contain and the number of animals. The data obtained are based on oral and written information received from business authorities.

\section{Results}

According to the results of survey, the numbers of public/city aquariums operating in Turkey are 13 as of November 2019 (Table 1). One tunnel aquarium is also under construction. The first public aquarium open to the public was opened in 2009 in Bayrampaşa, İstanbul. This aquarium, which was built in a shopping center, was opened with the name Turkuazoo. This facility, which has a total water capacity of $5000 \mathrm{~m}^{3}$, currently operates under the name of SEA LIFE İstanbul Aquarium. The first large public aquarium in İstanbul attracted great attention. Then, the second-largest public aquarium in İstanbul entitled İstanbul Akvaryum was opened two years later. The water capacity of İstanbul Akvaryum is around $6800 \mathrm{~m}^{3}$. During these two years, two large public aquariums were also opened in Ankara with the initiative of the local municipalities. Although, these aquariums, which started to operate in Ankara, are much smaller than the two large aquariums in İstanbul, and continue to attract a large number of visitors. After the first large aquarium was founded in 2009, the total number of large aquarium enterprises in Turkey has risen to 13. So, all of the major public aquariums in Turkey were established in the last 10 years. All of these enterprises are located in metropolitan cities such as İstanbul (5 units), Ankara (3 units), Antalya (1 unit), Bursa (1 unit), Diyarbakır (1 unit), Eskişehir (1 unit) and İzmir (1 unit) (Table 1). The vast majority (60\%) of large public aquariums in Turkey are located in İstanbul and Ankara which are the most crowded and the capital city of Turkey, respectively. Most of enterprises were established by supporting of local municipal investments. The greater part of them is operating in or near shopping centers. Among these aquariums, Antalya and İstanbul come to the forefront with respect to the criteria such as water capacity, the number of themes contained the tank presentations, animal variety, and the total area occupied.

\section{SEA LIFE İstanbul Aquarium (Turkuazoo)}

SEA LIFE İstanbul Aquarium is the first and the largest public aquarium in Turkey and it was established in 2009. This business was established under the name of Turkuazoo and then it was entitled as SEA LIFE İstanbul Aquarium because of the management change. This aquarium was built into the shopping mall called Forum İstanbul in Bayrampaşa, İstanbul. Its original investment is around 17 thousand Euros. By the representative of Indonesian company Global Aquarium in Turkey, İstanbul Underwater World Tourism Trade Inc. was established as Turkuazoo, and later passed into UK company Merlin Entertainments. When it was opened, its visitor numbers reached to 2500 at the end of the first week. Initially, it was reported that the number of visitors reached close to 1 million per year. It is an enterprise that could use the advantage of being the first public aquarium established in Turkey in terms of visitor numbers. According to the information provided by the establishment, approximately 320000 people visited this aquarium in 2018 .

More than 50 people are employed including aquaculture engineers, aquaculture technicians, aquanauts, biologists, visitor guides, and management staff in SEA LIFE İstanbul Aquarium.

The total water capacity in the aquarium is around $5000 \mathrm{~m}^{3}$. Totally 30 tons of sand was used in aquariums. There are 45 tanks in the facility, 8 of them are freshwater aquariums, and others are marine aquariums. The facility hosts 15478 nektons of 500 species. There is one large tunnel aquarium. In addition to one large main tank, other tanks are of various sizes, large and small.

The main species exhibited in the establishment are composed of species such as Bowmouth shark, sand tiger shark, Bonnethead shark, blackfin sharks, zebra shark, guitar shark, giant grouper, clownfish, reef flying gurnard, blue-faced African threadfish, seahorse, jellyfish, starfish, giant moray eel, cow nosed stingray, spotted freshwater stingray, black stingray, spotted common eagle ray, leopard stingray, bug-eyed soldierfish, nurse shark, octopus, brown crab, blue crab, stickleback bubble fish, lobster, queen triggerfish, batfish, lionfish, croc hunter chelonian, mata mata turtle, Danube sturgeon, red-bellied piranhas, discus, boxfish, long-horned cowfish, dragon eels, knife fish, horseshoe crab, sanitary shrimp, hermit crab, rainbow crab, tropical corals and stonefish. There is also SEA LIFE İstanbul Sea Turtle Rehabilitation Center in the facility.

\section{Keçiören Outdoor Aquarium}

This aquarium was established in 2010 by Keçiören Municipality of Ankara as an open-air aquarium in Fatih Sultan Mehmet Park in Etlik, Ankara. The aquarium is a marine aquarium with a length of 35 meters and a capacity of approximately 300 tons of water. This aquarium is introduced as the first and the only open-air aquarium established in Turkey. 
Table 1. List of public aquariums operating in Turkey (As of November 2019).

\begin{tabular}{|c|c|c|c|c|c|}
\hline Name of the Aquarium & $\begin{array}{c}\text { Year of } \\
\text { Establishment }\end{array}$ & Current Location & $\begin{array}{c}\text { Water } \\
\text { Capacity }\left(\mathbf{m}^{3}\right)\end{array}$ & $\begin{array}{l}\text { Number of } \\
\text { Tanks (pcs) }\end{array}$ & Number / Species of Animals \\
\hline $\begin{array}{l}\text { SEA LIFE İstanbul Aquarium } \\
\text { (Turkuazoo) }\end{array}$ & 2009 & Bayrampaşa, İstanbul & 5000 & 45 & $\begin{array}{l}\text { It is home to } 15478 \text { nektons of } 500 \\
\text { species }\end{array}$ \\
\hline Keçiören Outdoor Aquarium & 2010 & $\begin{array}{l}\text { Etlik, Ankara } \\
\text { (Fatih Sultan Mehmet Park) }\end{array}$ & 300 & & $\begin{array}{l}\text { It was opened with } 2230 \text { invertebrates } \\
\text { together with } 671 \text { sea fish in } 13 \text { species }\end{array}$ \\
\hline Deniz Dünyası & 2010 & Keçioren, Ankara & 1000 & 18 & $\begin{array}{l}\text { It accommodates } 4000 \text { marine and } \\
\text { freshwater species of } 150 \text { species }\end{array}$ \\
\hline İstanbul Akvaryum & 2011 & Florya, İstanbul & 6800 & 64 & There are 17000 land and sea creatures \\
\hline Kaplıkaya Cazibe Merkezi & 2011 & Yıldırım, Bursa & 3000 & 17 & $\begin{array}{l}\text { There are approximately } 5000 \text { fish in } \\
\text { tunnel aquarium and } 150 \text { fish in other } \\
\text { aquariums }\end{array}$ \\
\hline Aqua Vega Aquarium & 2012 & Ankara & 4500 & 24 & There are 12000 marine species \\
\hline Antalya Aquarium & 2012 & Konyaaltı, Antalya & 7500 & 64 & It hosts roughly 10 thousand species \\
\hline ETI Underwater World & 2014 & Sazova Park, Eskişehir & 1400 & & $\begin{array}{l}\text { There are a total of } 2150 \text { living creatures } \\
\text { in } 84 \text { species }\end{array}$ \\
\hline Viasea Aquarium & 2015 & Tuzla, İstanbul & 5200 & & $\begin{array}{l}\text { It has over } 12000 \text { marine creatures in } 47 \\
\text { different themed exhibitions }\end{array}$ \\
\hline Aqua Diyarbakır & 2015 & Diyarbakır & 1700 & 31 & $\begin{array}{l}\text { It hosts } 2500 \text { different marine creatures } \\
\text { of } 150 \text { species }\end{array}$ \\
\hline Jungle İstanbul & 2015 & Eyüp - İstanbul & & & \\
\hline $\begin{array}{l}\text { Emaar Aquarium \& Underwater } \\
\text { Zoo }\end{array}$ & 2017 & Üsküdar, İstanbul & & 48 & $\begin{array}{l}\text { It hosts over } 20000 \text { nektons and } \\
\text { amphibians of } 200 \text { species }\end{array}$ \\
\hline Funtastic Aquarium İzmir & 2018 & İzmir & 2000 & $70+$ & \\
\hline Aquarium Ortahisar & $\begin{array}{l}\text { Under } \\
\text { construction }\end{array}$ & Ortahisar, Trabzon & & $\begin{array}{l}1 \text { Tunnel } \\
\text { Aquarium }\end{array}$ & $\begin{array}{l}\text { It is expected to be the longest }(180 \mathrm{~m}) \\
\text { underground tunnel aquarium in the } \\
\text { world }\end{array}$ \\
\hline
\end{tabular}

When the aquarium was firstly opened, a total of 671 marine fish belong 13 species and 2230 invertebrates were exhibited. This aquarium serves in a way that people can visit for free.

\section{Deniz Dünyası}

It was established by Keçiören Municipality of Ankara was opened with the name of Deniz Dünyası (which is Marine World in Turkish) in 2010. It has a closed area of $2700 \mathrm{~m}^{2}$ and a total area of $4000 \mathrm{~m}^{2} .140$ thousand people were reported to have visited during the first two months of its opening. This facility consists of 12 tunnel aquariums, 7 special aquariums, a cylinder aquarium, a touch aquarium and a diving helmet aquarium. In addition, it has a $1000 \mathrm{~m}^{3}$ water capacity in total. In the facility, which hosts 4000 sea and freshwater fish and 150 turtles species, there are also 2 African crocodiles with a length of $1.5 \mathrm{~m}$. The aquarium prioritizes training programs, particularly, elementary school students are provided with educational information about marine species and marine life.

\section{İstanbul Akvaryum}

İstanbul Akvaryum (in Turkish; aquarium) is the fourth public aquariums after aquariums of Turkuazoo, SEA LIFE İstanbul Aquarium, and Deniz Dünyası according to the establishment date. However, it is the second public aquarium in terms of establishment concept and theme content. In addition, it is the largest aquarium in Turkey according to the water capacity at the establishment date, 2011.
It was opened with an investment budget of approximately 168 million TRY with the initiatives of the İstanbul Metropolitan Municipality. This aquarium, which was initially operated by the İstanbul Metropolitan Municipality, was transferred to a private company in 2013. The number of visitors who come to the aquarium in a year is reported to be approximately 1.2 million people. The enterprise employs approximately 200 people and approximately 500 people with its subcontractors and service units.

İstanbul Akvaryum has a thematic aquarium concept with 64 tanks of various sizes and has a total of $6800 \mathrm{~m}^{3}$ water capacity. According to the information given by the company, 17000 land and marine animals are exhibited. Its biggest living nekton is the lemon shark. Red-bellied piranhas, Russian sturgeon, anemones, clownfish, groupers, Gentoo penguins, stingrays, and anaconda are counted among the marine animals that it hosts.

It is a large thematic public aquarium. It consists of 17 themes and 1 rain forest following a geographical structure extending from the Black Sea to the Pacific. It is the first aquarium where all the seas are together.

\section{Kaplikaya Cazibe Merkezi}

It was opened in 2011 as Kaplikaya Cazibe Merkezi (in Turkish, Kaplıkaya Attraction Center) in Yıldırım, Bursa with the initiatives of Yıldırım Municipality of Bursa. This aquarium is designed in a slightly different way from the well-known public aquariums, has succeeded 
in attracting public attention. There are totally 5 employees; 2 divers, 1 machine technician and 2 aquaculture engineers in the aquarium. It has a tunnel aquarium and the tunnel aquarium is 25 meters long with a water capacity of 3000 tons. In addition, there are 2 aquariums with a volume of 50 tonnes, 4 aquariums with a volume of 6 tons, 10 aquariums with a volume of 1.5-2 tons. Two of these aquariums are marine aquarium while others are freshwater aquarium. Moreover, there are carp and koi fishes in the tunnel aquarium since it has an open water circulation system. There are 2 eels and clownfish in the marine aquarium, and various species of cichlid, catfish variety, gourami and crocodile fish in other aquariums. There are approximately 5000 fish in tunnel aquarium and 150 fish in other aquariums. These species are procured from within the country.

\section{Aqua Vega Aquarium}

Aqua Vega Aquarium was opened in 2012 within a shopping center in Ankara. It was established by the private sector with an investment of 17 million Euros. In the first year of its establishment, it hosted 500000 visitors. The main theme of this facility is a large tunnel aquarium with a length of $98 \mathrm{~m}$. 24 different aquarium components were used in the facility which has a water capacity of $4500 \mathrm{~m}^{3}$. It is stated that there are approximately 12000 marine animals in the aquarium where most marine animals are demonstrated. In this aquarium, it is possible to come across many nektons such as sharks, Koi fish, Napoleon fish, and clownfish. In the Wildlife Section, serval, Flemish giant rabbit, domestic ferret, marmoset, golden pheasant, African crocodile, mephitis, cotton-headed tamarin, a red-cheeked water turtle, and helmeted Guineafowl are also demonstrated.

\section{Antalya Aquarium}

It is the biggest tunnel aquarium of the world with a length of 131 meters and a width of 3 meters. Antalya Aquarium was opened in 2012 with the initiatives of the Antalya Metropolitan Municipality. It has been established in the Konyaaltı region of Antalya where the number of domestic and foreign tourists is quite high. It was established with an investment fund of 80 million TRY. This facility is located in the tourism region and therefore has a large visitor portfolio. Most of the foreign visitors coming to Antalya from other countries visit this aquarium. In this respect, Antalya Aquarium also plays an important mission for the presentation of Turkey. Since this company was established with the build-operate-transfer logic of the Antalya Metropolitan Municipality, it was transferred to a private company after a while. The number of visitors reached 1 million at the end of the first year, and reached 5 million within 7 years. Antalya Aquarium has nearly 50 employees, 24 of which are life support teams.

There are 64 aquariums of different sizes in the facility and 40 different themes are displayed. Total water volume of the aquariums is approximately $7500 \mathrm{~m}^{3}$. The water capacity of its main tanks is approximately $5000 \mathrm{~m}^{3}$. Although there are about 10 thousand living animals in the aquarium, most of these species are marine animals.

\section{ETİ Underwater World}

ETİ Underwater World, opened in 2012 in Sazova Park, Eskişehir, is an enterprise established in cooperation with Eskişehir Metropolitan Municipality and ETİ Company. This aquarium was launched with an investment of approximately 6.5 million TRY. The aquarium is capable of hosting 400 visitors at a session, and 3500 visitors in a day. The entrance fees have been kept at very reasonable levels. In this way, it was aimed to be able to host as many visitors as possible. It accommodated 2500 people on the first day of its opening and 100000 people in 24 days. ETİ Underwater World was established on an area of $2350 \mathrm{~m}^{2}$. It consists of more than 30 thematic aquariums, a 19-meter aquarium tunnel, and a tropical aquarium with poisonous and tropical amphibian species, Amazon River and sturgeon aquarium, terrarium, touch aquarium. A total of 2150 living animals belong to 84 species are demonstrated in the aquarium, which is a public aquarium rich in diversity.

\section{Viasea Aquarium}

This aquarium was established in 2015 by a private company within a shopping center in Tuzla, İstanbul. It has an investment value of approximately 1 billion TRY and is located in a theme park. In the first two days of its opening, it hosted 10000 visitors. The water capacity of this facility is approximately $5200 \mathrm{~m}^{3} .47$ different themed aquariums display over 12000 marine animals. This aquarium is the first largest public aquarium on the Asian side of İstanbul. It has the largest capacity among public aquariums in Turkey and also a rehabilitation center (quarantine area).

Visitors are also given the opportunity to walk around life support sections to show how a public aquarium is managed.

\section{Aqua Diyarbakır}

Aqua Diyarbakır is the first largest public aquarium launched in the Eastern Anatolia Region of Turkey. This company was also established by a private company in a shopping center with an investment of approximately 30 million TRY. The aquarium hosted 696 thousand people in the first 5 days of its opening. There is a team of 40 experts working in the facility including veterinarians, biologists, aquanauts, and aquaculture engineers. It has a water capacity of 1700 $\mathrm{m}^{3}$ with thematic aquariums, touch ponds, main tank (3 different concepts), and a 55-meter long tunnel aquarium with a total of 31 aquariums. It hosts 2500 different sea marine animals belong to 150 species, including sharks, piranha, lobster, and octopus.

\section{Jungle İstanbul}

This aquarium is also a thematic aquarium established by a private company in a shopping center. Jungle İstanbul was opened in 2015 in Eyüp district of İstanbul. The aquarium, which was established with an investment of approximately 650 million TRY, serves the visitors coming to the shopping center. In addition to aquariums, the property of the business is designed in a large theme park concept, where various tropical animals such as snakes, spiders, chameleons, crocodiles, frogs and exotic birds are on appearance.

\section{Emaar Aquarium \& Underwater Zoo}

This establishment was opened in a shopping mall in Üsküdar district of İstanbul. One veterinarian and 8 aquaculture engineers are employed in the aquarium. There are 48 tanks in various sizes in the facility. It hosts over 20000 marine and amphibian animals belong to 200 species such as shark and stingray species, shrimps, shellfish, coral 
reefs, jellyfish, snakes, spiders, iguanas, chameleons, wild piranhas, giant water rats, otters, red-cheeked turtles, arawanas, herbivore piranhas, thornback rays, Humbolt penguins, Macaw parrots, naked mole-rat, Cayman lizard), mini manta, giant spider crab, king crocodile.

It consists of 7 different thematic sections including rocky shores, main tank with tunnel aquarium (glass-like underwater tunnel with a 270-degree view of coral reefs 3.5 meters below the surface), jellyfish gallery, forests, rivers and waterfalls, penguin island, crocodile zone.

\section{Funtastic Aquarium}

Funtastic Aquarium is a medium-sized public aquarium that established in 2018 within a shopping center in İzmir. Its water capacity is approximately $2500 \mathrm{~m}^{3}$. In this facility, species such as sand tiger shark, stingray, blowfish, red-bellied piranha, moray eel, archerfish, clownfish, octopus, red arowana are exhibited. This aquarium is the first aquarium in İzmir.

\section{Aquarium Ortahisar}

It is still under construction. The aquarium planned to be built in Ortahisar, Trabzon. It is expected to be the longest (180 meters) underground tunnel aquarium in the world. This aquarium is established by the initiatives of the Ortahisar Municipality of Trabzon.

\section{Discussion}

Mankind's interest in caring for and protecting wild and domestic animals goes back to ancient times. So much so that Mesopotamia, Egypt, China and possibly India between 3000 BC and 1456 AD were the first known communities to have animal collections (Kisling, 2000). People's interest in animals led them to have animal collections. The epicenter of such animal collecting activities later spread to the Greco-Roman regions, the Persians and the Arab regions (Kisling, 2000). People's interest in animals first started with collecting activities, later on, there was development towards establishing zoos. The first animal species exhibited in zoos are of course were land animals. It has become a very popular field of activity to present wild species to people's tastes. After land animals, aquatic animals were also exhibited in zoos. This is how public aquariums were formed. The first large public aquarium known in the world was opened in 1853 at the London Zoo (Brunner, 2003). Since then, public aquariums have become a well-known and widespread activity all over the world.

Zoos and aquariums can be defined as exhibition spaces that offer thousands of different species to people's tastes. However, nowadays, zoos and public aquariums have social responsibility areas other than just exhibiting animals. These structures were also part of wildlife conservation activities. On the other hand, it has multifaceted positive outcomes that emphasize development of veterinary medicine, technology, education, park and recreation development, human sensitivities to nature and cultural change (Kisling, 2000). From this point of view, public aquariums have the power of raising awareness on various fields ranging from education to nature conservation besides creating a good time and entertaining people.

Large public aquariums, which have begun to spread between the second half of the 18th century and the first half of the 19th century
(Karydis, 2011), began to be established in Turkey after 2009 for the first time. As it is indicated in the present paper, the number of public aquariums operating in Turkey, having a population of around 82 million in 2019, is 13. All of these aquariums are located in provinces with the highest population density such as İstanbul, Ankara, İzmir, Bursa, Antalya, Eskişehir and Diyarbakır in Turkey. Predominantly, İstanbul is the province that has the most public aquariums. Almost half of the current aquariums in Turkey (5 aquariums) are operating in İstanbul. The largest two public aquariums in Turkey were established in İstanbul. People's interest in these two aquariums triggered the opening of public aquariums in İstanbul and other regions of Turkey.

The installation and operation costs of public aquariums are very high. For this reason, in order to sustain efficiently business, the income obtained from the visitors must be continuous. This is one of the primary reasons for the establishment of these aquariums in İstanbul, İzmir, Ankara and other metropolitan cities. There is a direct correlation between the sustainability of the business and the number of visitors to the aquarium. Since the investment costs are high, the local municipalities undertook these investments in many provinces. In addition to the economic gains of these structures built for the benefit of the public, their social contributions are very valuable.

Dozens of different tropical marine and freshwater species are on display in public aquariums in Turkey. However, it exhibits the most popular animals in demand such as sharks, stingray fish, tropical coral ecosystems, tropical marine fish, herd species, crabs, seahorses, piranhas, moray eel, which are the species more attracting the attention of people, as well as exotic animals such as crocodiles, penguins, water snakes. Species living in the seas of Turkey are exhibited as well as tropical species. A total of 67 fish species including 8 species belong to 4 ordo and 8 families from Chondrichthyes (cartilaginous fish) group, and 59 species belonging to 9 ordo and 24 families from Osteichthyes (bony fish) group have been identified in the waters of Turkey were reported in a study examining the species exhibited in public aquariums operating in İstanbul, Ankara, Bursa and Antalya (Gültekin et al. 2014). When the habitats of the detected species exhibited in aquariums are examined, it is observed that mostly benthic species (57 species) are preferred in the public aquariums (Gültekin et al., 2014). In addition, 6 semi-pelagic, 3 epipelagic and 1 pelagic species have been reported (Gültekin et al., 2014). In public aquariums in Turkey, 40 species living in the Black Sea, 48 species living in the Sea of Marmara, 62 species living in the Aegean Sea and in the Mediterranean Sea are known to be widespread (Gültekin et al., 2014). People also have the chance to see many aquatic organisms such as sharks, stingrays, eels, seahorses, crabs, lobsters, octopuses in public aquariums, which they cannot see in the regions where they live (Avc1, 2016).

\section{Conclusion}

Public aquariums significantly contribute to the educational activities of children, principally for children of small age groups. They can provide opportunities for people of all ages to have a good time and have fun with their families in these facilities. Public aquariums are also profitable commercial areas for operators. The number of 
visitors coming to some aquariums shows that public aquariums are also important commercial areas. Public aquariums are important for their economic and social contributions. In addition, they provide employment opportunities to many people who have been trained as aquaculture engineers, aquaculture technicians, biologists, veterinarians, and fisheries technology graduates. Given all these contributions, there is no reason why public aquariums should not continue their activities in the future. The total number of public aquariums in Turkey, which are currently 13 nowadays, can be expected to increase in the future.

\section{Conflict of Interest}

The authors declare that there is no conflict of interest.

\section{References}

Avc1 D. (2016). General structure and characteristics of city aquariums. Master's Thesis. Marmara University. İstanbul, Turkey.

Barnabe, G. (Ed.) (1989). Aquaculture (Vol $1 \&$ Vol 2). (2nd ed.). Paris: Lavoisier Technique et Documentation. 1344p.
Brunner, B. (2003). The ocean at home: An illustrated history of the aquarium. New York: Princeton Architectural Press. 143p.

Gültekin, K.B., Karadal, O., Türkmen, G. \& Özaydin, O. (2014). The marine fish species belongs to Turkish fauna exhibited in public aquariums. Ege Journal of Fisheries and Aquatic Sciences, 31(3):

127-132. https://doi.org/10.12714/egejfas.2014.31.3.02

Hugurenin, J.E. \& Colt, J. (1992). Design and operating guide for aquaculture seawater systems. Amsterdam: Elsevier. 264pp.

Karydis, M. (2011). Organizing a public aquarium: Objectives, design, operation and missions. A Review. Greece. Global NEST Journal, 13(4): 369-384.

Kisling, V.N. (2000). Zoo and aquarium history: Ancient animal collections to zoological gardens. (1st ed.). London: CRC Press. 440p. 